\title{
Impact of Legal Incentives on “Credit Fraud” Criminal Offence
}

\author{
Rezana Balla \\ PhD, Mesdhetar University of Tirana, Albania
}

Alketa Elezi

Prof. Assoc. Dr. Mesdhetar University of Tirana, Albania

\begin{abstract}
Currently, the number of financial institutions has been increased in Albania, which provides Albanian citizens with access to various financial services, mainly to obtain financing services in the form of microcredit. Given the history of our people, not all the Albanian citizens have had opportunity to have access and to benefit from various financial services. Denial of financial services is an issue that has affected not only Albania, but also other small Balkan countries. The reasons for this denial are numerous, but among them, we can distinguish the lack of lending experience, as one of the common reasons for being excluded in these countries from the development of the financial sector. Taking into consideration that, the growth of financial institutions led to the growth of financial services by raising awareness and financial education of citizens. Finally, the Bank of Albania ${ }^{1}$, as the supervisor of financial activities, intends to set a ceiling on the interest of consumer loans provided by non-bank financial institutions and commercial banks in Albania. This paper aims to present through a professional legal treatment all the challenges of the legal and institutional framework of the Bank of Albania, itself in undertaking this initiative. The questions we intend to answer through this paper are: Is the Bank of Albania legitimized to set a ceiling interest rate for consumer credit? What are the benefits or challenges that this initiative will bring to the financial sector? How will this regulation affect the criminal offense of "Credit Fraud"? How will the financial industry be designed after the implementation of the initiative? Will it have any impact on customer beneficial? etc.
\end{abstract}

Keywords: interest cap, consumer loan, financial serveces, credit fraud, microcredit.

\footnotetext{
${ }^{1}$ Bank of Albania is the Central Bank in Albania and has the supervising authority over second rank tier of banking system and the entire financial system.
} 


\section{Introduction}

One of the most recent legal initiatives that the Bank of Albania has undertaken recently is the designing of a Draft Regulation for some changes in the Consumer Credit $^{1}$. This initiative ${ }^{2}$ has been circulated to all financial institutions, such as banks and non-banks financial institutions, that exercises their financial activity in Albania, for opinions and consultation. In this context, through this paper we are expressing our opinions on this Draft Regulation.

Currently, the activity of financial institutions is increased significantly in the territory of the Republic of Albania. Including and increasing at the same time, the number of persons who benefit from financial services. This inclusion is a positive indicator for the formalization of the economy in Albania, because through financial services people are encouraged to open bank accounts and formalize their economic activity. And in this perspective, the Bank of Albania by exercising its competencies should supervise this financial market.

If we observe this activity from the point of view of law enforcement institutions such as the Police, the Prosecution, and the Court, we will see that the risk of committing the criminal offense ${ }^{3}$ of "credit fraud $4^{4}$ increases. Referring to the Report "On the state of Criminality in Albania during the year 2020" of the General Prosecutor ${ }^{5}$ at the Albanian Parliament, it results that the number of proceedings for this criminal offense, "credit fraud" is increased by 2.3 times. This high figure constitutes an issue that needs ${ }^{6}$ to be addressed not only by law enforcement institutions but as well as by regulatory institutions. So, the role of the Bank of Albania should be focused on strengthening the implementation of legal criteria rather than defining the interest cap as a competence that does not result in the range of its competencies.

In these times of the global pandemic, selecting digital finance for access to financial services is definitely a prerequisite, even a necessity. In the framework of the development and digitalization of financial services, it is intended to carry out the

\footnotetext{
${ }^{1}$ Decision of the Supervisory Council of the Bank of Albania no. 48 dated 1.7.2015 On the approval of the regulation "On Consumer Credit and Mortgage Credit".

${ }^{2}$ https://www.bankofalbania.org/Mbikeqyrja/Kuadri_Rregullativ_Mbikeqyres/Akte_ne_proces_ko nsultimi/ (September 1 $\left.1^{\text {st }}, 2021\right)$.

${ }^{3}$ Elezi, I,. \& Kaçupi, S,. \& Haxhia, M. (1999). Commentary on the Criminal Code of the Republic of Albania. Tirana: University Book Publishing House. 115-130.

${ }^{4}$ Criminal Code of Republic of Albania approved by Law no 7895, datë 27.1.1995, amended, published at Official Journal, several publications.

${ }^{5}$ General Prosecutor's Report for Criminality in Albania in 2020.

https://www.pp.gov.al/Media/Njoftime_per_Shtyp/Raportimi_i_Prokurorit_te_Pergjithshem_ne_K uvendin_e_Shqiperise_Mbi_gjendjen_e_kriminalitetit_per_vitin_2020.html (July 2021).

${ }^{6}$ Balla, R. (December 2017) Constitutional Reform, Criminal Justice Reform in the Prevention of Organized Crime and Corruption. Proceedings of the International Conference Faculty of Law, Tirana University. 368-376.
} 
process of remote identification of clients of the financial institutions. This fact is one of the basic issues related to the prevention of money laundering ${ }^{1}$ and the consumption of the criminal offense of "credit fraud". But let's look in a more concretely way, how this initiative for setting an interest cap on consumer credit will affect the treatment of these issues.

\section{Legitimacy of the initiative of the Bank of Albania}

Currently, the Bank of Albania is a Central Bank, of the first level and has the duty to supervise not only the performance of banking and financial activity in the territory of Albania, but also all other financial parameters that affect the economic indicators of the country. The Bank of Albania, according to the definitions made in the Law no. 82692, dated 23.12.1997 "On the Bank of Albania" as amended, is responsible to the Parliament of Albania and its main objective is to achieve and maintain price stability.

This law provides for the rights and competencies of the Bank of Albania in the framework of the transparency of its activity and the increase of the degree of independence, as well as provisions regarding the manner of organization and administration of the activity of the Bank of Albania. In all cases for the approval and/or amendment of the bylaws or sub legal acts it issues, it defines as legal basis article 12, letter "a" which explicitly states that: "The Bank of Albania issues normative and non-normative acts to ensure the stability of the banking system based on law and its implementation". Let's analyze this right or competence that the law gives to the institution. The Bank of Albania intends to give legal force to a sub-legal act, which in this case is the Draft Regulation, based on this general competence recognized by Law no. 8269. If we look at the date of entry into force of this law, we find that it was drafted and approved before the entry into force of the Constitution ${ }^{3}$. And as such it has not taken into account the provisions of Article 118 of the Constitution. The Constitution stipulates that the right to issue bylaws, ie acts that are lower in the hierarchy of acts ${ }^{4}$ than the laws, have only the institutions provided by the Constitution and the Bank of Albania is provided as such in Article 161 of the Constitution. But the constitutional legislator is not satisfied only with that right and the procedure of approval of bylaws, so only to determine the institution, but

1 Balla, R. (December 2018) Combating Money Laundering and Terrorist Financing, Amendments to the Law on Prevention of Money Laundering, published by the European Institute, SEE I EU Cluster of Excellence in European and International Law, Verlag Alma Mater, Saarbrucken, Germany. Series of Papers Vol. 4, 121-139.

${ }^{2}$ Law no. 8269 dated 23.12.1997 "On the Bank of Albania" amended, published at Official Journal.

${ }^{3}$ Constitution approved by Law no. 8417, dated 22.11.1998, as amended, published in the Official Journal, 1998. New amendments of the Constitution approved by law nr. 76/2016, date 22.07.2016, published on Official Journal no. 138 July 2016.

${ }^{4}$ Anastasi, A., \& Omari, L. (2010) Constitutional Law. Tirana: ABC. 154-167. 
continued with the definition of other criteria, without the fulfillment of which, the bylaw itself would be null, thus legally invalid.

According to the point 2 of Article 118 of the Constitution it is stipulated that: "The law ${ }^{1}$ must authorize the issuance of bylaws, by determining the competent body, the issues to be regulated, as well as the principles on the basis of which these acts will be issued." Thus, Law no. 8269, exactly Article 12, letter "a", defines a general provision providing for the competence of the institution to issue normative and nonnormative acts to ensure the stability of the banking system... If we refer once again to the criteria of point 2 of Article 118 of the Constitution, the law must authorize, in addition to determining the competent body for the issuance of bylaws, must also determine the issues to be regulated ${ }^{2}$, as well as the principles based on which these acts will be regulated. The provision of article 12 letter a) of Law no. 8269, does not provide for the issues to be regulated and the principles on the basis of which these acts will be issued.

Therefor, the authority of the Bank of Albania to issue sub legal acts, such as the Draft Regulation on determining the interest cap for the consumer loan agreement can not be considered fully in compliance with article 118/2 of the Constitution, because the law has not authorized issues that will be regulated and the principles on which these issues will be regulated.

In the same time, if we analize the competence given to the Sypervisory Council of the Bank of Albania for approving all sub legal acts, regulations and ordinances with general implementation that are issued by the Bank of Albania we can notice a general competence for approving any sub legal acts. That sublegal act only by the fact that is approved by the Supervisory Council must have legal enactment. But the Constitution has stipulated restriction on this kind of discretion a general one for all sub legal acts. The institutions only because they are foreseen by the Constitution can not issue any different sub legal acts, but only the one that is authorized by the law. Therefor, suddenly comes out a question taking into consideration the fact that the Constitution stipulates that the law has the authority to delegate the competence at the constitutional institution to issue a specific and concret sublegal act by determing the issues that will be regulated and the principles based on which the issues will be regulated, has the law authorized the Bank of Albania to issue the Draft Regulation on determining interest cap for consumer loan?

\footnotetext{
${ }^{1}$ Based on the Law Drafting Manual (2010) - A guide for drafting laws in Albania. Tirana published by the European Union, Ministry of Justice and EURALIUS. 58-89.

${ }^{2}$ Balla, R. (2005) Some recommendations on the drafting of normative acts in order to harmonize and unify legislation. Scientific Journal Parliamentary Law and Legal Policies, 25, 28-43.
} 
If we refer to article 44, point 4 of the Law no. $9902^{1}$ date 17.04.2008 "On Protection of Consumers" amended, this law has determined only the competence of the Bank of Albania to regulate by sub legal act the consumer loan. But how can we interpret that it is authorized the establishment of the interest cap as well by this provision? Even this prediction is debutable on the given competence to the Bank of Albania. So, it is not clear whether it is aimed the establishment of interest cap. Taking into consideration that Draft Regulation of the Bank of Albania on Consumer Loan is drafted and entered into force since 2015 and by that time was not addressed as an issue to be treated or regulated by the sub legal act.

Therefor, if we refer to article 124, point 8 of the Law² 9662 dated 18.12.2006 "On Banks of the Republic of Albania" amended, the Bank of Albania may determine by a sub-legal act requirements and other criteria for the client protection during his beneficial from the banking and financial services foreseen by the law.

Based on the legal basis we analyzed above, we find that in any case the competence/authority ${ }^{3}$ of the Bank of Albania to determine the interest cap of the loan contract is unclear and not fully in compliance with the constitutional criteria. As the Constitution stipulates that issues which will be regulated should be clearly authorized by law, and not only this but also the principles on the basis of which these issues should be regulated.

\section{Constitutionality of the Draft sub-legal act}

Currently, one of the basic criteria needed for Albania's membership in European institutions is the implementation of the Rule of Law. According to which to guarantee legal certainty, that everything is regulated by law and all activities must be carried out in accordance with the law. According to the Constitution, Article 4/1 provides: "The law constitutes the basis and limits of the activity of the state".

According to the Constitution, Article 11 stipulates that freedom of private economic activity is guaranteed. This freedom is one of the newest concepts that has taken place in modern constitutions and mainly means the right to enter into contracts, individually or collectively, freely and on the basis of personal will, the right to choose the activity that the individual wants to exercise, the right to have a job according to preference, etc. In this context, individuals have autonomy and are free to determine for themselves the terms and type of civil contracts they will enter with each other, provided that these legal actions do not contradict the prescriptive norms of the law. Of course, like all other rights and freedoms, the Constitution also stipulates those restrictions may be imposed on them, but they can only be exercised by law, and it

\footnotetext{
${ }^{1}$ Law no. 99021 date 17.04.2008 "On protection of consumers" amended, published at the Official Journal.

2 Law no. 9662 dated 18.12.2006 "On Banks of the Republic of Albania" amended, published on Official Journal.

${ }^{3}$ Omari, L., (2005) Principles and Institutions of the Public Law. Tirane: Pegi. 134-165.
} 
can be justified that they are exercised only to protect the public interest. Specifically, the provision of Article 17/1 of the Constitution provides: Restrictions on the rights and freedoms provided in this Constitution may be established only by law, in the public interest or for the protection of the rights of others. The constraint must be proportionate to the situation that has dictated it. This type of delegation recognized by the Constitution is limited and the deviation from the definition determined by law of criteria and procedures directly related to a delegated right, creates legal uncertainty, bringing direct implications to the freedom of economic activity, protected by Article 11 of the Constitution.

Likewise, based on the hierarchy of acts provided by Article 116 of the Constitution, it is provided that an act that is lower in the hierarchy of acts can not provide or regulate differently from what is provided by an act that is higher in the hierarchy of acts. According to law no. 9662, dated 18.12.2006, "On Banks in the Republic of Albania", as amended, the bank and the branch of a foreign bank regularly announce the terms and conditions for calculating interest rates, related to monetary deposits, or loans and changes their methodology of calculation, according to the manner and form provided in the bylaws of the Bank of Albania". So, banks and financial institutions have the exclusivity as they really had for determining the interests. The Bank of Albania is authorized to determine the manner and form with further details by sub-legal acts. Which is confirmed in the legal provisions of Article 124 point 8 that we analyzed above. So, in this case the law has provided that financial institutions can determine and regularly announce the conditions for calculating interest rates. In this way, the bylaws, ie the regulation that the Bank of Albania intends to undertake, contradicts the definition that has been made by law and as such, based on the hierarchy of acts, is legally null.

At the same time, in article 53 of law no. 9662, dated 18.12.2006, the legislator/Parliament emphasizes the importance of transparency towards the client (without interfering in the content of the contractual relationship with the client) as follows "Banks ... publish interest on monetary deposits, loans and commissions for services rendered, as well as the methodology for calculating interest on monetary deposits and repayment of loans. In cases when the Bank of Albania finds that the publications mentioned in points 1 to 4 of this article are inaccurate or incomplete, it orders their correction and republishing".

According to the Draft Regulation, we conclude that "The object of this regulation is to determine the requirements on the content and manner of providing precontractual and contractual information of consumer credit and mortgage credit to the consumer, as well as the regulation of consumer credit and mortgage credit." Thus, the competence of the Bank of Albania is limited to determining the requirements on the content and manner of providing pre-contractual and contractual information but not to determining the interest cap as intended to regulate the proposed Draft Regulation. 
Regarding other countries, especially the European ones, we find that most of them have aimed to leave the regulation of credit prices or the determination of the effective interest rate to the free market ${ }^{1}$, to the development of the economy itself. Thus, of the European countries only France and Germany have set cap to interest rates, but this is limited to small credit packages. Other countries of the European Union and beyond do not set limits but allow them to self-regulate by free market activity. As one of the most democratic pricing tools according to the demand-offer mechanism. The welfare implications of interest rate regulation are therefore heterogeneous, as they distribute the risk to the borrower, while the benefit of stronger hedged borrowing regulation is the harm to excluded borrowers.

\section{Cases of "Credit Fraud" Prosecution and Court}

As we presented above, with the increased number of institutions that exercise microcredit activity, the risks faced not only by the institutions, but also by society as a whole have increased. It is true that these institutions facilitate the procedures for obtaining credit and increase the involvement of individuals in obtaining loans. Access which has not been possible before by banks. However, the creation of these facilities does not mean that we should benefit unjustly, by going as far as consuming the criminal offense "Credit Fraud".

According to the Report of the General Prosecutor, only for 2020, the criminal proceedings for this criminal offense "Credit Fraud" have increased by 2.3 times. Moreover, the concern is even greater when it is found in many cases that these acts were committed in collaboration, turning it into an organized crime case. Case that we will be discussed below. This concern has also been presented in the visual and print media.

Based on article 146 of the Criminal Code it is defined that Fraud in Credit constitutes "fraud in the submitted documents, unjustly by obtaining credit fictitiously registering in the mortgage objects that do not exist, or beyond their real value, or owned by another, of made in order to not repay the loan taken". According to the Criminal Code, this offense is punishable by a fine or up to seven years imprison.

The most common form of this fraud in recent years has been obtaining bank loans with forged documents or using the means of identifying other persons. These offenses have become a concern for some banks and non-bank financial entities, not only because of the economic damage they have suffered, but also because of their considerable reputational damage to the market. Third parties who have fallen victim

\footnotetext{
${ }^{1}$ Microfinance Center findings on Covid-19 financial impact. This paper summarizes the data collected by the Microfinance Centre (MFC) through a survey of microfinance institutions in Europe to assess the impact of COVID-19 crisis on the situation of microfinance institutions and their clients. www.mirofinancecenter.org (June20 $\left.{ }^{\text {th }} 2021\right)$.
} 
to fraud through the use of documents and their signature to obtain credit in some cases have denounced the events in the media.

One of the most flagrant events last year was the case of an employee of a financial institution in Fier, who through forgery of documents and signatures of other persons has withdrawn 17 loans in their name for a total amount of more than 900 thousand ALL. At the end of the investigation, it turned out that the documentation for obtaining loans were not signed by the persons, on whose behalf they were signed, but were falsified by the employee of the financial institution ${ }^{1}$, the person under investigation P. B, benefiting the relevant amounts.

Several people have been arrested by the police in Berat who had created a fraud scheme, through which they recruited various people, in exchange for reward, taking their identification documents to enable the benefit of microcredit from these financial institutions. The Prosecution ${ }^{2}$ of the Judicial District of Berat started the criminal proceedings in 2020 and with the Decision of the Court of the Judicial District of Berat $^{3}$ no. 211 dated 09.02.2021 all defendants were convicted. From this fraud scheme there were about 22 victims who were materially and morally damaged.

A fraud recently discovered by police and employees of a second-tier bank in the city of Shkodra - a well-thought-out scheme by a young boy. The "fraudster" was exactly a 22-year-old, whom in cooperation with employees of this bank, turns out to have taken loans on behalf of other citizens, more than once. This scheme was discovered when the bank contacted a person who was a debtor, but in fact, he had not taken any action nor had taken a loan from this bank.

All these cases caused damage to banks and financial institutions, both financial and reputational damage, therefore employees are required to responsibly implement the policies and regulations of the bank and financial institutions.

\section{Conclusions}

Based on the legal basis we analyzed above, we conclude that in any case the competence/ authority of the Bank of Albania to determine the interest cap of the loan contract is unclear and not fully in compliance with the constitutional criteria of Article 118 thereof. After all, the Constitution stipulates that the law must authorize the institution and the issues to be regulated by a sub-legal act, the competence must be made clear, as well as the principles on the basis of which these issues should be regulated. Also, the provision of the Draft Regulation contradicts Article 116 hierarchy of acts of the Constitution. In this context, based on the analysis performed above, in relation to the Draft Regulation of the Bank of Albania, for determining the

1 Refered on the criminal case registered by the Fier Judicial District Prosecution on year 2020.

${ }^{2}$ Refered on the notification for the completion of investigations with no. 188/32 Prot., Dated 10.09.2020, for the criminal case no. 39 of 2020.

${ }^{3}$ Decision of the Court of the Judicial District of Berat no. 211 dated 09.02.2021. 
interest cap of consumer credit, we are of the opinion that it implies the principle of activity and economic freedom and hierarchy of acts, in the Republic of Albania.

The Draft Regulation creates legal uncertainty for the financial entities, to which this act is addressed, does not define clear rules, conditions, and criteria for the exercise of lending activity, violates the principle of legal certainty related to the exercise of economic rights and market freedom. The provisions of this regulation contain discriminatory criteria that do not guarantee free competition and conflict with the application of the constitutional principles of "equality under the law" and "freedom of economic activity of citizens", thus violating the functioning of the rule of law.

On the one hand, the tighter regulation of credit interest limits the ability of banks and financial institutions to operate with the power of the free market. On the other hand, a forced adjustment of loan interest can consider market segments as losses for banks and financial institutions, thus impairing access to credit for beneficiaries.

Under these conditions, the focus should be on the fight that should be performed through regulatory and institutional measures to prevent the commission of criminal offenses of "Credit Fraud" by not allowing paths to favor the commission of this criminal offense.

\section{Bibliography}

[1] Balla, R,. (December 2018) Combating Money Laundering and Terrorist Financing, Amendments to the Law on Prevention of Money Laundering, published by the European Institute, SEE I EU Cluster of Excellence in European and International Law, Verlag Alma Mater, Saarbrucken, Germany. Series of Papers Vol. 4.

[2] Balla, R., "Some recommendations on the drafting of normative acts in order to harmonize and unify legislation", published in the scientific journal "Parliamentary Law and Legal Policies" 2005.

[3] Balla, R., "Constitutional Reform, Criminal Justice Reform in the Prevention of Organized Crime and Corruption", Proceedings of the International Conference Faculty of Law, 2017.

[4] Constitution of Republic of Albania, published on Official Journal 1998. New amendments of the Constitution approved by law nr. 76/2016, date 22.07.2016, published on Official Journal no. 138 July 2016.

[5] Criminal Code of Republic of Albania, 1995.

[6] Decision of the Court of the Judicial District of Berat no. 211 dated 09.02.2021, final form.

[7] Decision of the Fier District Prosecution for the completion of investigations with no. 188/32 Prot., dated 10.09.2020, for the criminal case no. 39 of 2020.

[8] Decision of the Supervisory Council of the Bank of Albania no. 48 dated 1.7.2015 On the approval of the regulation "On Consumer Credit and Mortgage Credit". 
[9] Elezi, I,. \& Kaçupi, S,. \& Haxhia, M. (1999). Commentary on the Criminal Code of the Republic of Albania. Tirana, University Book Publishing House.

[10] General Prosecutor's Report for Criminality in Albania in 2020.

[11] Law Drafting Manual - A guide for drafting laws in Albania, published by the European Union, Ministry of Justice and EURALIUS, Tirana 2010.

[12] Law no. 8269 dated 23.12.1997 "On the Bank of Albania" amended, published at Official Journal

[13] Law no. 9662 dated 18.12.2006 "On Banks of the Republic of Albania" amended, published on Official Journal

[14] Law no. 99021 date 17.04.2008 "On protection of consumers" amended, published at the Official Journal.

[15] Omari, L. (2005) Principles and Institutions of the Public Law. Tirane: Pegi.

[16] Omari, L., \& Anastasi A., (2010) Constitutional Law. Tirana: ABC.

[17] This paper summarizes the data collected by the Microfinance Centre (MFC) through a survey of microfinance institutions in Europe to assess the impact of COVID-19 crisis on the situation of microfinance institutions and their clients.

\section{Web pages}

[1] www.mirofinancecenter.org, (June 2021).

[2] https://www.bankofalbania.org/Mbikeqyrja/Kuadri_Rregullativ_Mbikeqyre s/Akte_ne_proces_konsultimi

[3] https://www.pp.gov.al/Media/Njoftime_per_Shtyp/Raportimi_i_Prokurorit_ te_Pergjithshem_ne_Kuvendin_e_Shqiperise_Mbi_gjendjen_e_kriminalitetit_p er_vitin_2020.html

[4] https://www.bankofalbania.org/Rreth_Bankes/( June 2021). 